\title{
フォッサマグナの基盤構造と現在の地殼運動
}

\author{
徳山明*半田孝 司* \\ Structural Framework and Recent Crustal \\ Movements of the Fossa Magna
}

Akira Tokuyama and Koji HANDA

\begin{abstract}
100 years have past since Edmund NAUMANN discovered the Fossa Magna in 1876. He thought it as a kind of large rift dividing the Japanese arc into the northeastern and southwestern limbs. He regarded the islands as a single Palaeozoic folded zone and afterwards transversed by the rift accompanied by volcanic zones. On the other hand Edward SuEsS and Toyokichi HARADA considered the islands in terms of two tectonic units, the northern Sachalin System and the southern Chinese System, joined in the manner of syntazis in the Fossa Magna. Since the argument of NAUMANN vs. HARADA concerning the tectonic units of Japanese islands, hot discussions have continued concerning the tectonic signifficance of the Fossa Magna.

After structural analyses of the folded zones in the Akaishi Mts., the senior author has confirmed the Fossa Magna as a large meridional left lateral fault, holding $100 \mathrm{~km}$ 's of displacement. It is accompanied by a large and wide drag zone in the western side, consisting of minute and numerous faults and cracks. Owing to the fragmentation of the drag zone, there has been no large earthquake in these areas. In order to confirm very slow crustal movements and regional strains of the fault zone, we measure precise distances among several radial and triangular nets in the zone by means of an electro optical instrument "Geodimeter 700 ". Results of surveys are also summerized in this paper.
\end{abstract}

はじめに

フォッサマグナはナウマンが1875年に来日して最初の調査旅行の折，11月13日に発見したと云う。次節 にナウマン自身の発見の記(1893) から当時の模様を抄訳したいと思うが，本州を横切る大裂罅である事及 びこれに沿って火山が並んでいる事が彼の第一印象であった。その後ナウマン一原田の論争として良く知 られる対曲説など，フォッサマグナに関する種々の解釈が行なわれたが，ナウマンの第一印象の 2 点以上 の事柄はわからなかったと云っても良い。大塚彌之助（1948等）はフォッサマグナ地帯をかなり詳しく踏 査したもののこの地域の新第三系のみの調査に終始したために，大断層帯と云いながら，フォッサマグナ が例えばどのような地殼運動に由来するのかとか，又断層とすればどのような変位を有するか等の本質的 事柄には触れられずに了っていたし，これが又富士山等の火山と如何なる関係にあるかも分らなかったの である。新第三系の褶曲に関しても，地層の分布や層相の解析は行なったものの，これらの地層を構成す

* 静岡大学教育学部地学教室 Faculty of Education, Shizuoka University 
る岩石がどのような変形を受け, どのような変形組織をもつかと云った褶曲の解析は行なわれていなかっ た。またフォッサマグナの西縁の位置に関しての議論はあるものの, 赤石山地の基盤構造に関する知識が なかったために，何をもって西縁とするかの明確な定義には至っていない。

徳山は赤石山地の四万十帯や瀬戸川帯の褶曲構造を解析し, 更に身延・下部等の新第三系の変形を解析 することにより，フォッサマグナ帯周辺地域の基盤構造を明らかにし(1972a，1972b)，これによりフォッ サマグナが変位量 $80 \mathrm{~km}$ にも及ぶ大規模な左横整れ断層である事，その西側赤石山地には幅 $60 \mathrm{~km}$ に及ぶ 広範囲の引き摺り帯がある事が判った。その後この基盤構造の引き摺り帯がフォッサマグナ地域に頻発す る山地災害と密接な関係があること（1975a）がわかり，更に伊豆半島沖地震もこのフォッサマグナ周辺 の基盤構造と同根の地殼運動であることも判明した (1975c)。このように考えると，フォッサマグナの地 凯運動は現在も進行していることは明らかであるから，この地殼運動が現実にどのような形で進行してい るかを測定する事を目的として, フォッサマグナ地帯の数地に基線を設け精密な光波測量を開始した。現 実に測量を開始して見ると, 器械の精度, 測定の精度, 測定の方法についても様々な問題がある事がわか り, 器械の公称精度の 100 万分之 1 を確保する事は非常にむずかしい事がわかった。国土地理院, 東大地 震研究所の協力・助言の下に標準的測定法の開発を試み, 本学における測定基線を作製する迄に数年を費 した(半田，1976)。このようにして一応納得のできる測定を開始した矢先に昨年来の「駿河湾地震」又は 「東海沖地震」の騒ぎが抽り，3年間の短い測定結果ではあるが，東大地震研究所とわれわれの共同の 小笠小型基線網の測定值（表 4 ）と, 国土地理院の坂部基線網の測定值（表 5 ）の積み重対が，数少ない 実証的証拠となり，「当面さしせまって巨大地震が起こる前兆はない」といら結論が出るに至ったことは 地元の研究者として欣快であった。

この機会にナウマンが発見した当時をかえりみ，フォッサマグナの基盤地質構造の視点からの問題点を 述べ，あわせてこの地域の光波測量の結果を報告したいと思う。

国土地理院の吉田光雄技官及び東大地震研究所の柴野睦郎氏に注光波測量の方法につき数々の御助言を 賜つた。この機会に厚く御礼申し上げる。尚本稿に於いて, 地質構造に関する記述については徳山が責任 を負い，光波測量の測定については半田・徳山が責任を負ら事を附記する。尚本研究は德山に配分された 文部省補助金科研費（154267）を使用した。

\section{I. フォツサマグナの発見}

フォッサマグナ発見の時の模様をナウマン（1893）は「フォッサマグナへの旅」として，この論文の第 2 部フォッサマグナの章の第 1 節に紀行文風に綴って発見の印象を述べている。

1875年 8 月17日に日本に着いたナウマンは最初の調查に浅間山と千曲川の谷を選び，当時の天長節の翌 朝11月 4 日早朝に東京を出発した。中仙道を通り高崎から赤城・妙義を横に見て碓氷峠から追分に入っ た。此処で何泊かして浅閒山に登山した後, 千曲川の谷を南に逆上った。海の口から谷をはなれ, 夜荒涼 とした原野を抜け約 $1300 \mathrm{~m}$ の国界の峠を越えたのは11月12日であった。嵐をはらんだはやて雲が西側入ケ 岳の峨々たる峰をかけぬけていた。雲間から折しも満月の月光が深い谷に黒いかげを刻んでいた。この峠 を下りその夜つかれ果てて平沢の部落に入った。ナウマンはそこの旧家に泊ったよらであるが，その夜の 嵐が物凄く, 吹き荒れる風と戸障子のガタガタなる音で一晚中眠れなかったという。明けて11月13日嵐が 過ぎて, 前夜とは打って変った晴天に南を見ると, 右に $3000 \mathrm{~m}$ を越える赤石の山脈がそそり立ち, その東 縁は南にまっすぐに延びる絶壁が媣い釜無の谷に面している (口絵写真 1 参照)。左手には浅間からの山脈 の続きが壁をなし，その地溝の南東に富士が力強く天にそびえていた。壮絶な嵐の一夜と澄み切った翌朝 と云う演出効果満点のこの“フォッサマグナ”とのドラマチックな出合いはナウマンにとっては忘れ得ぬ ものだったのであろう。「地球上にこのフォッサマグナと比べられるような割れ目があり得るだろらか」 と云う強い表現を使っている。その第一印象で, 本州の構造方向を横切りにする割れ目 (Querspalte) で 


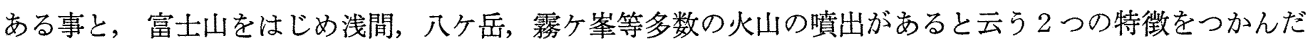
ナウマンは，この割れ目の地形的特徴と，国際的な意義を考えて, Fossa Magna と云うラテン語の名前 を提唱したのであった。

ナウマンの最初の調查旅行は此処で引き返し, その後高野から霧ケ峯の方に踏み入れているょうであ る。その後, 此フォッサマグナを調查するために翌1876年 7 月には菶科から諏訪湖へ抜け塩尻峘から大町 一抜け，此処で采魚川一静岡線を見ている。 3 回目は 1883 年 7 月に甲州街道を通り, 小仏峠の小仏層, 上 野原の桂川磁や御坂層の緑色凝灰岩を見て, 吉田から富士山に登った。7 月26日夕方 5 時頂上に着いたナ ウマンは此処でまた，フォッサマグナ西側の壁をなす赤石連山の絶景に目をらばわれる。「 $3000 \mathrm{~m}$ を越え て笟え立つ赤石山塊の巨人は今フォッサマグナの門屝を北西に開いた」その続きに八ケ岳, 金举山と煙を 噴く浅間山，その間に関東山地がブォッサマグナの東側の丸い高まりを見せ，東に向ってだんだんと低く なり遂に関東平野に潜る。更に足下を見ると, 河口湖から 精進湖を経て天子山脈まで褶曲の列 (Faltenzüge）が環状に富士山を取り巻いている事, 丹沢や天子の閃緑岩, 玢岩等もこれら御坂の御坂凝灰岩類と 共にこの褶曲に関倸がある事，そして富士山は宝永，鷲巣，愛鷹などを連ねて北々西一南々東方向の割れ から噴出して居り, それもこの環状裮曲列に関係があると考えた。また, 伊豆の山地や箱根, 伊豆大島も 同じ方向にのびた棈円形であり，これ同様フォッサマグナの Wegweiser であると考えた。

ナウマンはフォッサマグナ全体にわたって調査したわけではないが，其後のフォッサマグナを趈る議論 で問題になった事に就いては殆んど気がついていた事がわかる。

\section{II. フォッサマグナを廻る諸説}

フォッサマグナに関する論争で最も有名なのはナウマン一原田の論争と云われるものであるが，原田豊 吉の意見は当時のウィーン大学の教授 Edward SUESS (1883) の説をそのまま受け入れ 2 つの弧が会合し たもの (Scharung) と考えていたようである。ナウマンも述べているように会合はヒンズークシュとヒマ

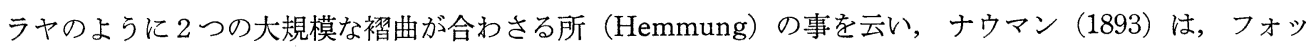
サマグナにはこのような解釈を当てはめる事はできないと述べた。前述の会合の場合 $2 つ の$ 褶曲帯の方向 は内から外に向っているが， 日本の場合，フォッサマグナを狭みその西側も東側も褶曲が北から南に向い ており， Scharung の場合とは逆であるとも述べている。何よりも，ナウマンはこのフォッサマグナを挾 む西南日本の褶曲帯と東北日本の褶曲帯は同じ一続きの褶曲帯であった事を強調し, フォッサマグナが後 にこれを切って発達した事, 従って, 七島弧がここで本州と交わっている事も偶然ではなく，その割れ目 と火山作用との結び付きを考えていたようである。これに対し原田は日本を南日本弧のシナ系と北日本弧 のカラフト系の 2 つ別の弧が会合したと考えている。

西南日本と東北日本の褶曲の基本的な構造は, 其後の研究により一連のものであることは明白でありナ ウマンの考え方が正しい(小林, 1941)。

ナウマンは原田の考えに対し，10項目について両者の意見の相違点を述べつつかなり克明に論評してい るが，ナウマンの記述を見ると原田の調查は技術的に必ずしも当を得たものではないと批判している。例 えば原田が諏訪湖を爆裂火口（Maar）と述べている事を取り上げ，このような事は日本の事を知らない読 者が読むとアイフェルと同じ様な印象を持つかも知れないが，とんでもない事であると云った強い語調の 処があり，自分の考えは明瞭でわい曲されない事実にもとずいていると述べ，暗に，実際の調査もせずに 説を立てた SUESS の批判も行なっている。

事実この文に引用している観察結果を見るかぎり，前述の西南日本と東北日本の基盤構造が一連である と云った大きな点を除いても御坂山地の観察等, ナウマンの指摘の方が妥当性が大きく, 若き日のナウマ ンの慧眼に軍配を挙げざるを得ない。

フォッサマグナについては日本の地質学の摇籃期のナウマン, 原田の説を受け継いで, 小川环治 (1907), 
リヒトホーヘン等の考えもあり，これらを矢部長克が総括して論じた(1919)。その後日本群島の構造発達 を論じた際小林貞一（1941）はナウマンの考えの正しかった事を述べている。一方大塚彌之助 (1948, 1952等）はこの地域の第三系を調查し，御坂山地の東北東一西南西方向と南部フォッサマグナの南北方向 の交錯を「手打沢不整合」に求め, 本質的には原田の解釈に従った。松田時彦（1958）ら其後の“ターシ ヤリスト”達はいずれも大塚に従っているが，これらはいずれも周辺地域の先第三系の地質構造を顧みな かったための初歩的な誤りに気が付かなかったようである。

南北方向の褶曲が卓越すると解釈された南部フォッサマグナ（松田，1958）の新第三系も砂岩や䃋岩層 のゲフューゲを調べて見ると，実は御坂山地と同じ北東一南西方向の褶曲軸が卓越しているのであって， 南北方向の裮曲軸と云うのは一度北東一南西方向に褶曲した基盤がもう一度新しい断層運動で切られて捲 れ上った為の後生変形による表層的な見かけだけのものであることもわかった(石川, 1972 ; 徳山, 1972a)。

フォッサマグナのいわゆる西縁の位置に関し，ナウマンは「静岡から岩脈状に御坂まで南北に延びる噴 出岩類の西側」と述べている。だがこれは現在の十枚山構造線のことであってこの線は実は西の瀬戸川帯 がフォッサマグナの左横摺れによって北に引き替られた為の境で，瀬戸川帯とその南に位置していた大 崩, 高草山の立武岩類を含むいわゆる大井川帯との閒の東西方向の衝上断層が引き摺りによって転移し, 南北方向の境界になり，赤石の東に位置する事になったものである。断層の位置は従ってこの「噴出岩脈」 の中にあって, 大塚 (1948）の云うように，静岡市麻機から竜爪山の東肩を通ると考えるのが正しい。こ の断層線沿いには竜爪山の南則沢に見られるように非常に幅の広い破砕帯を伴っている。この南北方向の 噴出岩を含む带が今日のいわゆる竜爪山帯であって, 玄武岩類のみでなく, 大井川帯の砂岩や頁岩を含む 褶曲層が引きちぎられた破砕岩の多い帯である。

このように考えると，フォッサマグナ西側の静岡大崩海岸の枕状溶岩は断層により其東の富士川沿いの 市川大門附近に分布する高萩山の玄武岩まで摺れたと考えると，周辺部の瀬戸川と小仏層群の替れ，赤石 山地と関東山地の四万十帯及び秩父・三波川帯の位置の摺れとも良く符合する。フォッサマグナ西側の引 き摺り帯は更に西側のいわゆる飛龮外縁帯や，青海橋立の三郡変成岩の構造（坂野，1956）にもあらわれ ていることがわかる。

断層の変位量を考える時，とかく垂直変位のみに目をうばわれやすい。例えば新第三系の基盤をなす 中・古生層がフォッサマグナの 西側の赤石や姫川の西では 現在露出しているが, 断層の東には新第三系 が地溝を埋めていて基盤が出ていない事からこの断層の変位が著しいと云う考え方（矢部，大塚ら）があ るが, この垂直変位はせいぜい新第三系の厚さの数キロであって, この断層を境とする南北の替れの変位 量が，大崩一高萩に表わされる70 80キロに比べるとわずかなものである。この摺れに気が付かないでい ると，例えばフォッサマグナ新第三系の礫岩には，赤石山地がすぐ西に接してあるのにこれからの䃝が含 まれていないから，これらの硳は東側から供給された（松田，1958）と云った単純な考えになる。実はこ

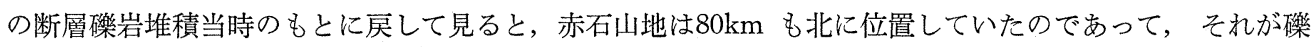
の直接の供給源地では有り得ない事は明白な事であって, この事から供給源が東であると考兵るのは論理 的におかしい事に気が付いていない。逆にこの整れを考えると中新統の相良地域の男神女神の礁性石灰岩 及び其周辺相の二枚介フォーナと，断層の東に位置する早川橋西の小原島のフォーナや御坂山地から桂川 地域に点在する石灰岩小塊との層相上の密接な関連を説明するにも都合が良い。

このようにして, フォッサマグナの周辺構造からの摺れと同時にフォッサマグナ新第三系の変形そのも のも明らかになり，ナウマンの発見以来100年にして，漸くその全貌が明らかになったのである。

\section{III. 静岡地域における基盤構造の引き摺り}

静岡地域の基盤構造に関してはすでに述べたように（徳山，1972b)，フォッサマグナ西側の赤石山地に は主として白㤠系から成る四万十帯と，主として古第三系から成る瀬戸川帯が分布し，その南に主として 


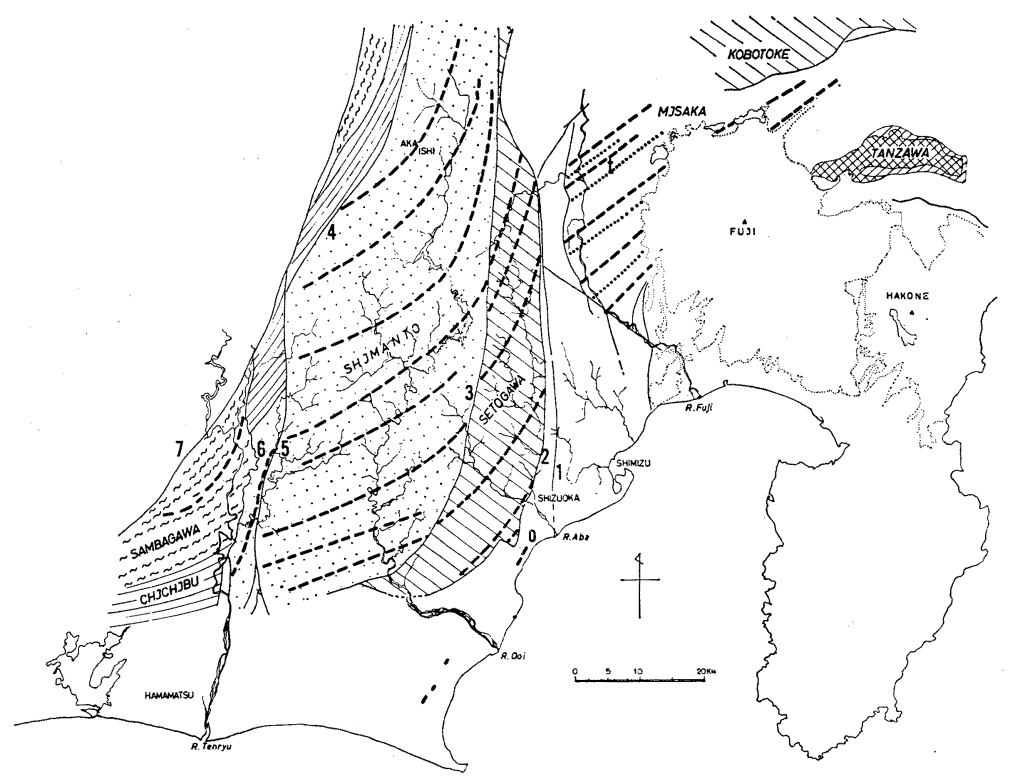

図 1 静岡地域の地質構造図（徳山，1972b）より転載）, 破線は各褶曲帯の主な背斜軸を示し, 点線は主な向斜軸を示す。 $\mathrm{O}$ : 大崩玄武岩 ; $\mathrm{t}$ : 高萩玄武岩 ; 1 : 糸魚川一静岡線 $; 2$ : 十枚山構造線；3:笹山構造線； $4:$ 仏像構造線； 5 : 光明東断層；6:赤石裂線 (光明西 断層)；7: 中央構造線。

中新統から成る大井川帯が位置している。瀬戸川，四万十両帯の褶曲構造を解析した結果，両带とも，西 から東方のフォッサマグナに近付くに連れて, 袏曲軸面が東西方向から南北方向に向きなおり, 東北東一 西南西方向から北々東一南々東，更にほぼ南北方向にまで曲って来ることが判明した (1972b)。褶曲軸面 は通常広範囲にわたり同一方向で平行であることが多く，浜松以西のいわゆる西南日本地域では内帯・外 帯を問わずほぼ東西方向であり，これは広汎に発達するスレート䢃開や粒子の並び換えている面等のゲフ ューゲとも一致している。

東北日本に扔いても，方向は異なり南北に近いが，同時代の褶曲帯の面，線等のゲフユーゲは広汎にわ たり一定，並行である（徳山1972a)。このいわゆる赤石スフェノイドで褶曲軸が約60km の幅の狭い範囲 で東西方向から北に彎曲し，フォッサマグナに収斂しているのは，2 次的な後生变形によるもので，最初 からこの様な彎曲があったわけではない。

四万十帯では特に井川北の地域は北々東方向に曲り，これより北の烟薙ダムょり北の赤石山地では更に 南北に近い方向になる。この彎曲に伴って四万十帯と瀬戸川帯の境界の衝上断層の笹山構造線も南北方向 に向きをかえる。この断層はもともと笹山の東を通る南北方向の断層に名付けられた（望月ら，1958）も のであるが，四万十帯や瀬戸川帯の構造解析が進むにつれ，これが四万十・瀬戸川両裮曲帯の境界をなす 衝上断層である事がわかった。この断層は岡部町青羽根附近から西では南西方向で，更に大井川沿いの神 座附近では西南西から東西方向に近くなる。

瀬戸川帯の褶曲軸も西方から東のフォッサマグナに近付くに従って北方に彎曲し，大井川附近ではほぼ 東西であるが，安倍川沿いの梅ケ島以北の早川沿いの新倉や夜叉神峠附近では $\mathrm{N} 20^{\circ} \mathrm{E}$ からほぼ南北にか わっている。

更に南の構造要素の, 大崩・高草山の玄武岩や相良の石灰岩を含むいわゆる大井川層群にも同様の関係

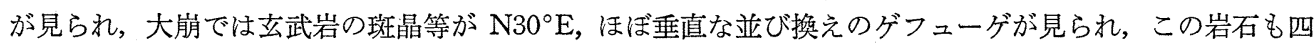


万十・瀬戸川帯の上うな古期の褶曲帯と全く同様のスレート䢃開に伴ったゲフューゲがある事がわかる。

西側は御前崎から南の海中に没し不明であるが，東側は糸魚川一静岡線に収斂するいわゆる竜爪帯とな る。

これらの地質区分を采魚川一静岡線をはさみ東側の地域の地質と比較すると, 御坂山地以北の関東山地 西部では南から御坂, 小仏, 四万十, 秩父, 三波川帯の諸褶曲帯が帯状に分布し, 断層西側と良く一致し ている。

大崩高草山の玄武岩と市川大門附近の高萩玄武岩は共に枕状溶岩を含み広い分布を示す似た岩体である から, 上述の瀬戸川一小仏帯以前の褶曲帯の横搖孔変位量を考えると, もともと同一岩体であったものが 断層によってこの位置まで替れたと考えるのが良い。

断層の東側记富士川沿いに西八代, 静川の中新統が分布するが, 下部や身延地域では褶曲軸部に砂岩 や啋岩の粒子の並び換えや頁岩部にはスレート辟開が見られ，その方向は北東一南西方向である（徳山， 1972a)。このような変形様式は藤枝北方の中新統砂岩中にも見られるが, 瀬戸川帯や四万十帯などの褶曲 帯の変形と同様であって, 変成岩を含む丹沢の褸曲帯の西の延長と考えられる。最近荒井1によよ大崩玄 武岩中及び高萩玄武岩からもブドウ石，パンペリ石等の変成鉣物も同定され，このような考え方が裏付け られた。

このようにして，フォッサマグナの主断層は70 $80 \mathrm{~km}$ の変位量を有する南北方向の左横摺れ断層であ ることがわかったが, この断層は大塚（1948）の調査のように静岡市麻機から桜峠, 則沢沿いに北上し竜 爪山の東肩の穂積神社の西を通り, 相又沢の屈曲点から七面山を通り角瀬にぬける。相又沢附近でいわゆ る竜爪帯の契が消滅し, 笹山構造線に一致し, これから北ではナウマンの云うように瀬戸川帯の東端の境 となる。この断層は早川沿いの奈良田，西山温泉を経て夜叉神峠まで追跡できる。

この主断層の東には由比附近の入山断層や身延附近の曙断層の上らに南北方向の平行な断層がいくつか あり，場合によっては松田（1958）の調查のように捲れ上りを伴ったり，またブロック毎に回転して引き 摺られていることもある。相又沢では主断層と曙断層にはさまれた地塊では中新統の褶曲軸はほぼ東西方 向であり，曙断層東で $\mathrm{N} 40^{\circ} \mathrm{E}$ となるので，ブロック毎に引き摺りや回転の様子が異なることがわかる。

一方曙断層東の富士川沿いの下部や天子地域の中新統の 裮曲構造を見ると, $\mathrm{N} 40^{\circ} \mathrm{E}$ 方向でかなり直線 的であり, 本栖湖附近で $\mathrm{N} 60^{\circ} \mathrm{E}$, 下部の $40 \mathrm{~km}$ 北東の河口湖で $\mathrm{N} 70^{\circ} \mathrm{E}$ 位となり, この部分では赤石山地 の引き摺り帯に比べれば彎曲ははるかに小さい。ここではこの中新統の褶曲帯を富士山の噴出物が広くお おってしまうので，丹沢の変成岩を含む褶曲軸の直接西の延長が富士川沿いのどの褶曲軸に対比できるか 不明であるが，河口湖背斜と平行に延長すると天子山附近から南部町や富沢町附近に続く䇢である。この 附近には丹沢附近の凝灰岩に比し層位的にはかなり上位の礫岩が露出しているので, 丹沢のような結晶片 岩はないが，礫岩の砅が回転変形を行い，小褶曲の軸部では北東一南西方向でほぼ垂直の面に沿って並び 換えているのを見ることがある。

このよらに主断層の西と東に分布する広い引き摺り帯までも含めて考えると，フォッサマグナは幅 100 $\mathrm{km}$ にも及ぶ広、断層带と云うことになり, 又引き摺り帯の分も加えて断層東の褶曲軸が東西方向の位置 から西側の東西方向に戻る位置まで考えると，横摺れの変位量は $100 \mathrm{~km}$ を越える大きな断層帯であるこ とがわかる。

\section{IV. 引き摺り帯のメカニズム}

主断層西の赤石山地の引き摺り带について考えるために，新倉西の四万十帯の結晶片岩が分布する背斜 軸を追跡すると, この軸は新倉から大井川の東を南下し, 烟薙ダムの南東, 東河内川から大井川本流を西 に横切り, 寸又川の奥逆河内から戸中山に抜け, 西の光明断層で切られている。この背斜軸だけから考え ると引き摺りの量は $50 \mathrm{~km}$ に及び, 引き摺り帯の幅は笹山構造線と光明断層の間の $30 \mathrm{~km}$ の範囲である。

1）口答のコメントによる。荒井博士に感謝する。 
このように大規模に彎曲する引き摺り帯はどのようにしてできたのであろうか。またこのように大きな引 き摺り帯は現在の地質現象にどの上うな影響をもつのであろうか。

赤石山地, 特に大井川の上流域は山崩れ等の山地災害の大変多い処であり, 崩壊の多い個所は引き摺り 帯の地域と一致しているように思われるので, この事を統計的にしらべた(徳山，1977)。

$1 / 20,000$ の空中写真で崩壊個所をしらべ，これを $1 / 5$ 万の地形図にプロットして崩壊個所図を作製し， これを $1 / 5$ 万地形図で $1 \mathrm{~cm}$ 平方の栘に区切って崩壊個所の数, 面積等を算出して原図とし, これをコン ピューターに打ち込み，一方地形，地質等の諸要素をコンピューターに打ち込んで，これらとの相関々係 を見た2〉。その結果崩壊個所は特定の地層の部分に比較的多く集中している事，断層近くに多い事，並び に井川より北の赤石山地を中心とする地域には大きな崩壊が多い事がわかった。褶曲軸が $\mathrm{N} 30^{\circ} \mathrm{E}$ より南 北近い北部山地では 1 メッシュ当りの崩壊数が平均して約 0.9 であるのに対し, $\mathrm{N} 50^{\circ} \sim 60^{\circ} \mathrm{E}$ の方向を 有する地域では 1 メッシュ当りの崩壞数は 0.05 と非常に少ない。褶曲軸が元々東西方向であったと考える と, 左横摺れの引き摺り量の多い地域と崩填の多い地域が一致している事になる。一方, もともとの褶曲 軸等と崩壊地域との関係をしらべると，この方は特に大きな相関はなく，地下深部で形成された褶曲構造 そのものは崩壊には関係ない事がわかる。

即ち裮曲軸部ではスレート䢃開, 粒子の並び換えやレンズ状破砕等のゲフューゲの発達が著しいがこれ は地下深部の高封圧下で形成されたものであり，これらの割れ目はいわば閉じて居り，崩壊と直接の関係 はない。もっとも風化はこれらの割れ目に沿って進行する事が多いから，風化に関係がないわけではな い。これに反し，ここでの断層や引き摺りによる後生変形は地質的には最近におきたものであり，いわば 活構造である。侵食が現在活発に進んでいるわけであるから, 現在地表附近に露出している部分は後生変 形の形成時にも地表附近にあった事, 即ち地下の比較的浅い処での変形になる。従ってこの引き摺りによ る後生変形では変形に伴う割れ目は開口しており，このために引き摺りと崩壊個所が関係あると解採され る。井川北の東河内川流域で, 同一層群の砂岩を構造的にも同一の褶曲軸部でのみ採集し, 超音波の伝導 度, 滅衰の度合をしらべると（徳山，1975a)，断層に近い処程割れ目に直角な方向での伝播が悪い。これ を伝播速度の異方性で見ると断層の近くの $1 \mathrm{~km}$ 以内になると平行方向は $5.5 \mathrm{~km} / \mathrm{sec}$ であるが, 直角方向で は $2.5 \mathrm{~km} / \mathrm{sec}$ 位になる。超音波伝播速度の最大最小の相乗平均から得た平均伝播速度は断層に近付くに従 い次第に減少し, 断層から $3 \mathrm{~km}$ の処で $5 \sim 5.5 \mathrm{~km} / \mathrm{sec}$ であったものが約 $2 \mathrm{~km}$ の地点で $4.5 \sim 5.5 \mathrm{~km} / \mathrm{sec}$, $1 \mathrm{~km}$ の処で4.0 4.5km/sec 位となり，断層に近付くにつれ超音波が伝わりにくくなっている。一方こ の平均伝播速度と最大最小值の差との比であらわす異方度は, 断層から $2 \mathrm{~km}$ 位までの地点迄はほとんど 変化せず 0.1 以下であるが，この辺から急に上昇し $1 \mathrm{~km}$ 位の処では $0.3 \sim 0.4$ となる。このように断層に近 付くと割れ目は急に開口している事がわかる。この異方性は超音波の減衰では特に著しい。超音波の減衰 は前述の地下深部の褶曲による割れ目や粒子の並び換えの方向でもある程度はあるが，割れ目が開口して いない限りあまり大きいものではない。この調查ではその点を配慮し背斜軸部のみのサンプルを用いてい るので, 後生変形前の原岩の異方性はほぼ同一と考えてよいから，ここにあらわれた断層近くでの減衰は 後生変形によるものである。

以上の事からこの赤石スフェノイドの引き摺り帯の彎曲は褶曲軸面の既成の割れ目と断層にほぼ平行の 南北方向の新たな割れ目が開口してそれに沿って少しずつ褶れ動いた為に生じた事がわかる。この細かい 割れ目は断層に近付く程, かつ引き摺り量が多い程多くなるので, これが現在の奥大井地域の山地崩壊と も関連があるのである。

大井川上流域にはほとんど峡谷らしいものがないが，これは上流域の岩石が，変成褶曲した四万十帯の

2）この作業は県林業会議所が中心となった林野庁の環境調查として行なったもので，コンピューター の読み取り作業はアジア航測が行ない，徳山は地質図の作製，崩壊に関係ありそうな地質要素の選 定等を行なった。 
堅ろうな岩石であるにもかかわらず，細かく破砕されている為に切り立った崖を保持し得ない事を示して いる。

赤石の大きな彎曲帯はこのように開口した細かい割れ目に沿って少しずつ替れ動いてできたのである。 横摺れ断層の変形様式には 2 種類あり，1つは単一の剪断面によって摺れる型であり, 引き摺り帯を伴 わず，他は共役の剪断面が細かく発達して広い範囲の地域がひずんで引き摺り帯となる場合である。1つ の円形の地域を仮定すると, 前者ではその円が剪断面により半円に切れて摺れ動き喰い違い, 後者では引 き皙り帯では円形部分が楕円形に変形し歪む。前者では喰い違いの変位量は大きいが, 半円形の形で残り, 他の部分に変形はない。これに反し後者の場合元の円形全体が棈円形に変形する。フォッサマグナの彎曲 を伴う引き摺り帯は後者の地域全体が歪んでいる例に相当する。

このような変形はフォッサマグナの西の光明断層・赤石裂線（木村, 1959）やフィリピン断層（木村, 徳 山他, 1968), ボルネオのキナバル断層（徳山, 吉田, 1974）など太平洋西側の大横替れ断層の一つの特 徵である(徳山, 1975b)。一方引き摺り帯を伴わない単一の剪断面による断層の例としては根尾谷断層が 挙げられる。この地域には山口帯が分布するが, 褶曲軸はほぼ東西方向で直線的であり, 断層を挾み東と 西の両側で平行に摺れており, フォッサマグナのような彎曲した引き摺り帯はない3)。両側での背斜向斜 の軸を比較すると，この断層による摺れの変位量は $4 \sim 5 \mathrm{~km}$ であると考えられる。この断層では濃尾地 震の際に生じた水鳥の断層崖が有名であるが，このような断層運動が少なくとも1000回は繰り返されない とこの変位量にはならないことになる。

\section{V. フォッサマグナの最近の地殼運動}

前述のよらにフォッサマグナの断層では，丹沢の褶曲帯が大きく摺れているので，この断層は地質的に は極く最近生じたと考兄られる。大崩玄武岩や下部附近のスレートのゲフューゲはこの褶曲帯形成後の後 生変形を意味している。丹沢の褶曲や変成の時期を正確にきめることはむずかしいが，この褶曲に中新統 最上部乃至鮮新統下部の西八代層群に砂の並び換えがあるので, これらの地層の堆積後更に或る程度地層 が重なり少なくとも $2 \sim 3 \mathrm{~km}$ の深さに埋没して後に裮曲ができた事になるから，鮮新世中期以降である ことは間違いない。この褶曲帯が引き摺り帯をも含めれば $100 \mathrm{~km}$ 以上も摺れていることを考えるとフォ ッサマグナは恐らく現在も活動しているであろら。

この断層はほぼ南北方向で左横替れであるが，その主圧縮応力軸の北西一南東方向と富士，浅間，箱 根, 伊豆等の多くの火山の長軸方向や岩脈の方向が一致している事から考えると, これらの火山はこの横 摺れ断層運動の羽状割れ目に噴出したと考えられる(徳山，1972b)。このように解釈すると，ナウマンが 富士山の頂上で考えた北西一南東方向の寄生火山群も当然このフォッサマグナの断層運動と関連があり, かつこのような火山活動と関連している事はこの地殼運動が現在も尚続いている事になる。1930年の北伊 豆地震や1974年の伊豆半島沖地震（徳山，1975c）も同じ地殼運動のあらわれである。

このようにフォッサマグナ全体としては現在も尚活動が続いているので，この地殼運動がどのような形 で進行しているかを考えることは最近話題になった「駿河湾内の巨大地震説」とも関連があり緊急かつ肝 要な事である。

静岡大学では1972年以降光波測距儀 AGA 社ジオジメーター700型による観測を開始したが，これは静 岡を中心とするフォッサマグナ地域の地殼運動を長期にわたり継続して測定したいと考えたからである。

この測距儀で測定できる距離は $5 \mathrm{~km}$ を限度としているので, 国土地理院の規格による三等三角網以下 の小型基線が測定の対象となるが，このような小型の基線でフォッサマグナ全域をカバーする事はできな いので, 以上でのべた構造地質学上重要と考えられるいくつかの地域を選定した。選定の視点としては第 1 にフォッサマグナの主断層の采魚川一静岡線又はその近くの地域, 第 2 亿現在確実に動きつつある地域,

3）1966年度特定研究費研究成果（p. 100，図 1）に報告。 


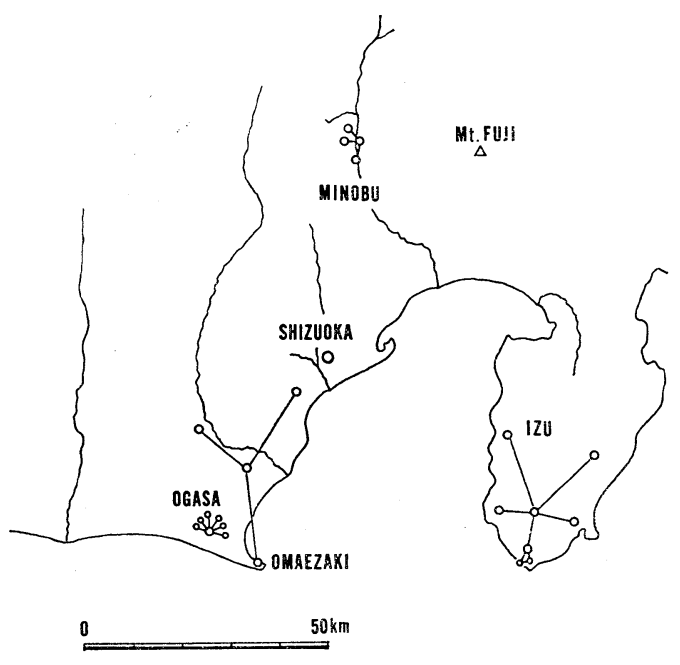

図 2 フォッサマグナ地域の光波測量基線網

第 3 に引き替りの比較的少ないやや安定した地域 を考えた。実際の測定に当っては，少しでも長期 の観測データを積み重ねたいと考え，同型の光波 測距儀で測定している東大地震研究所の基線網の 一部をそのまま継承することとし，身延，小笠の 基線網（笠原他，1968）についてはそのまま継続 観測を行っている。これらを含め現在継続観測を 行っているのは次の諸地域である。

1. 糸魚川一静岡線を中心とする地域

a. 静岡地域而等及びIV等三角網....

○片山（IV等）上り沓谷 $(\mathrm{III})$, 沼上 (III)

○沓谷（III）一沼上（III）を基線とし，大岩村

(III)及び賤機山（静大新点）の三辺測量。

これらの三角点はいずれも基盤の上に設置 されており，沓谷一沼上の基線と賤機山一大 岩村の間を糸魚川一静岡線が 通っているの

で, もしこの断層線が動けば三辺の差により移動量が算出できる。

b. 身延基線…東大地震研究所基線網（笠原他，1969）帯金上り身延橋, 三光堂, 山額の放射基線

この基線は曙断層を跨いでいることになっているが，それよりも放射基線による地域歪をとらえる ことの目的が大きい。

2. 現在確実に動いていると思われる地域

a. 南伊豆基線網

○青野（II）上り入間（II），岩科（II）の国土地理院二等三角網

○入間（II）, 長津呂（III）及び仲木（静大新点）の三辺測量。

これらは伊豆半島沖地震以降の余効地殼運動を捉える目的で継続しているが，1977年には一応終息 したと考えられる。

3. 引き摺り現象のあまりない比較的安定していると思われる地域

小笠基線網…河東山を中心とした放射 6 方向の半円形の基線（いずれも東大地震研新点）

この地域は引き摺りが比較的少ないので地域的変形を測定する目的で設置された。

以下に伊豆，身延，小笠の各基線網について現在までの結果を報告する。

南伊豆基線網の結果（図 $3 \mathrm{~A}, 3 \mathrm{~B}$ ，表 1,2 )

1974年 5 月伊豆半島沖地震がおこり南伊豆町に多数の地割れや小断層ができた（徳山，1975)。この事か ら震源地域ではかなりの地殼運動があったと考え, 光波測量により地殼変形を測定しょうと試みた。幸い 青野を中心とする国土地理院の II 等三角点の放射状基線がジオジメーターVIII型により1972 年に測定されて いたので，東大地震研究所と協同で地震直後にこの改測を行った。天候の関係で青野から入間，岩科の 2 測線しか測定出来なかったが，その後の国土地理院の改測により，他の 3 測線の範囲には地殼変形はなか ったことがわかった。

この結果南伊豆では割れ目の生じた範囲の青野から南西の地域が北西南東方向に短縮し, 北東南西方向 に延び，この 2 方向での最大歪は10-4 亿達した(徳山，1975；表 1 )。

尚この測定で注目されるのは1975年 2 月の地理院の測定で, 地震以後の 6 月以降 8 ケ月間に, 地震直後 に測定した歪の約 $0.6 か ゙$ 追加され, 地震後の余効変形の量が大きい事であった。ジオジメーター壮型による 
表 $1 \sim 5$ 光波測量成果

表1 青野村基点加らの南伊豆地域中型基線光波測量成果（単位： $\mathrm{m}$ )

\begin{tabular}{|c|c|c|c|c|c|c|}
\hline 測線 & 鉢山 & 郷 & 間 & 岩 & 一 & 備 \\
\hline 1. 1973 II & 14446.799 & 7016.990 & 7941.823 & 6676.958 & 13531.736 & （国土地理院） \\
\hline 2. 1974 VI & & & 7941.882 & 6676.901 & & (静岡大, 東大地震研) \\
\hline 3. 1975 II & 14446.862 & 7017.053 & 7941.914 & 6676.865 & 13531.747 & (国土地理院) \\
\hline
\end{tabular}

表 2 南伊豆地域三辺光波測量成果（単位: $m$ )

\begin{tabular}{|c|c|c|c|c|}
\hline 期日 測線 & 中木一入閒 & 中木一長津呂 & 入間一長津呂 & 積 $\left(\mathrm{m}^{2}\right)$ \\
\hline 1. 1975. VI & 2306.669 & 1322.125 & 2072.301 & 1357986.298 \\
\hline 2. $1976 . \mathrm{V}$ & 2306.675 & 1322.143 & 2072.301 & 1358004.445 \\
\hline (2.) $-(1)$. & +0.006 & +0.018 & 0.000 & +18.147 \\
\hline 3. $1977 . \mathrm{V}$ & 2306.675 & 1322.142 & 2072.303 & 1358004.547 \\
\hline (3.) $-(2)$. & 0.000 & -0.001 & +0.002 & +0.102 \\
\hline
\end{tabular}

表 3 帯金基点からの身延地域放射基線光波測量成果（単位： $\mathrm{m}$ )

\begin{tabular}{|c|c|c|c|}
\hline 期日 測線 & 山 & 三 光 堂 & 身 延 橋 \\
\hline 1. $1974-4-22$ & 2243.797 & 2390.248 & 2877.675 \\
\hline 2. $1974-11-19$ & 2243.798 & 2390.245 & 2877.674 \\
\hline 3. $1976-11-16$ & 2243.805 & 2390.242 & 2877.683 \\
\hline 4. $1977-4-28$ & 2243.801 & 2390.253 & 2877.685 \\
\hline
\end{tabular}

表 4 河東山基点からの小笠地域放射基線光波測量成果（単位： $\mathrm{m}$ )

\begin{tabular}{|c|c|c|c|c|c|c|c|}
\hline 期日 測線 & 海 戸 & 大 & 山 & 木 & 野 & 中田原 & 備 \\
\hline 1. $1974-2-1$ & 3751.405 & 3560.290 & 4802.124 & 4697.168 & 3997.290 & 5241.339 & （東大地震研） \\
\hline 2. $1974-10-31$ & 3751.399 & 3560.290 & 4802.122 & 4697.167 & - & 5241.348 & $\begin{array}{l}\text { (東大地震研・ } \\
\text { 静岡省 }\end{array}$ \\
\hline 3. $1976-11-8,9$ & 3751.404 & 3560.291 & 4802.128 & 4697.177 & 一 & 5241.348 & （静岡大） \\
\hline
\end{tabular}

表 5 坂部村基点からの御前崎地域中型基線光波測量成果（単位：m）

\begin{tabular}{|c|c|c|c|c|c|}
\hline 期日 測線 & 高 草 山 & 横 & 御 前 崎 & 備 & 考 \\
\hline 1. 1974. IV & 18335.451 & 13071.670 & 18487.715 & (国土地理院) & \\
\hline 2. 1975. XI & 18335.441 & 13071.643 & 18487.713 & $\prime \prime$ & \\
\hline 3. 1976. XI & 18335.446 & 13071.659 & 18487.724 & $\prime \prime$ & \\
\hline
\end{tabular}




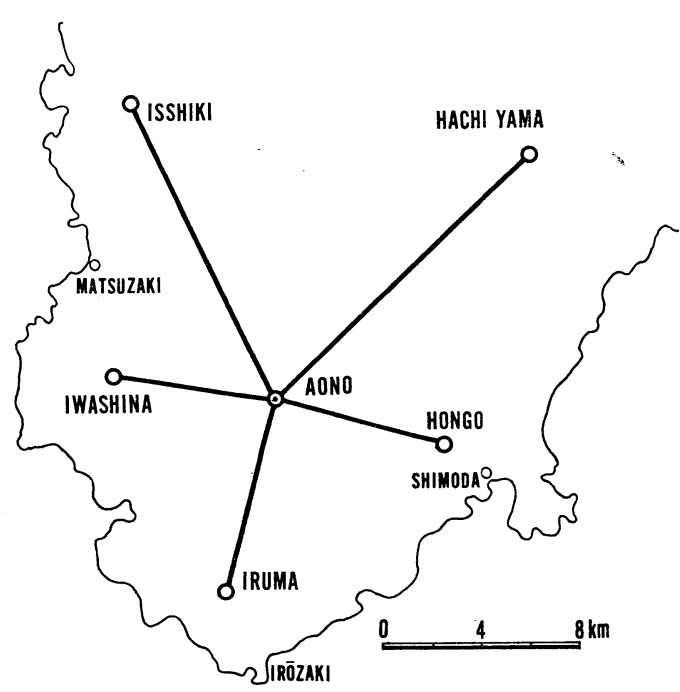

図 $3 \mathrm{~A}$ 南伊豆放射基線（国土地理院）

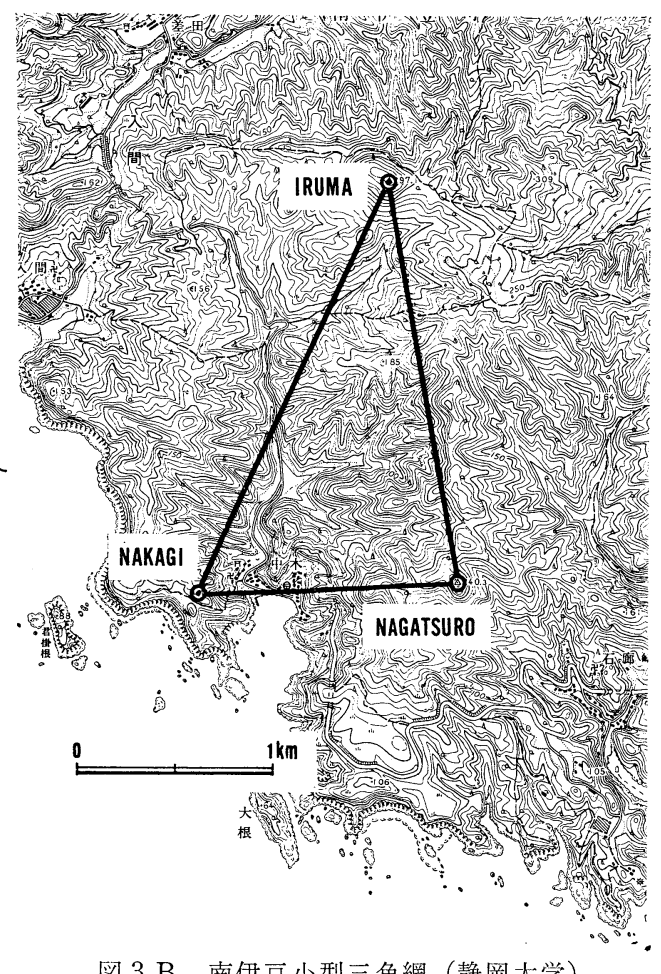

図 $3 \mathrm{~B}$ 南伊豆小型三角網（静岡大学）

改測はかなり手間がかかるので，其後地殼変形のあった仲木に測点を設置し(図 3 B) 入間一長津呂一仲木 の小型基線を設置し三辺測量による継続測定を行った。この結果表 2 の通り入間一長津呂の辺に対し仲木 点が1975 1976年の 1 年間に $18 \mathrm{~mm}$ 北西に移動し，この三角形の面積は $18.15 \mathrm{~m}^{2}$ 増大した。1977年の改測 では各辺共1976年の測定と全く等しいので，前述の余効地殻変形は 2 年間で一応終息したと考えて良い。

尚余効地殼変形については石廊崎の断層でも地質調査所の垣見等により測定されているが（宮沢, 衣笠, 1977), その量 $\mathrm{A}$ 点での $\mathrm{BD}$ 辺の $1.85 \mathrm{~cm}$ は地震の時の変位量の $40 \mathrm{~cm}$ に比し小さい。既に指摘した通り, 地震断層ができて地震時に活動した部分では余効現象は小さく，この放射基線内であまり大きな断層ので きなかった地域では余効現象が長く続いたと解釈される。

身延基線の結果（図 3 , 表 3 )

身延基線は東大地震研究所で設置し(笠原ら, 1968), 1967年以降の測定があり, 最も古い基線の一つであ るが, 途中測定点標石の埋設換えや測定機種がジオジメーターIV型, VI型, 700型と変わった事もあって, この間の機械や精度の更正が充分でない事もあって, 正確なデータが得られるようになったのは最近であ

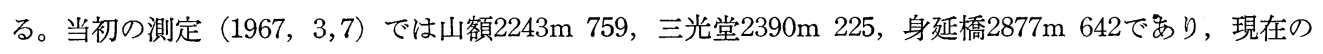
測定值とはやや異っているが，これは有意の地殼変形を意味しているとは考えられない。

小笠基線の結果（図 $5 \mathrm{~A}, \mathrm{~B}$; 表 4,5 )

小笠基線は東大地震研究所の柴野により設置された, 河東山を中心とする半円形 6 方向の放射基線で新 野而等三角点以外は東大の新点である。1974年以後の測定結果は表 4 のとおりで, 1974年は静大, 東大協 同で, 又1976年には静岡大学が改測し，それぞれ機械の更正も行ってある。この基線は半円形なので, 地 域的な歪を捉える目的で設置してある。例えば北西一南東方向からの圧縮があった場合, 北西一南東方向 の測線が縮み, 又北東一南西方向の測線が延びる筈であり, この基線では長さをそろえてあり半円形にし 
てあるので,計算に便利である(図 $5 \mathrm{~B}$ )。 この基線の成果は表 4 のと抢りで, 約 3 年間にほとんど意味のある変化はな い。

尚この放射基線とほぼ同じ時期に国土 地理院では坂部を中心とする大型基線を VIII型で測定し(図 $5 \mathrm{~A}$ ), それらの結果は 表 5 のと抢りである。この 2 つの光波測 量の結果は同時に1976年12月の地震予知 連絡会に提出され公表されだ)。

図 1 の通りこの 2 つの基線はほぼ同じ

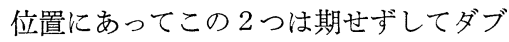
ルチェックする形となり相互のデータの 信頼度を確かめる結果となった。

\section{VI. フォッサマグナ地域の 地震活動と地殼構造}

フォッサマグナを中心とする地域には 大きな地震がなく, いわゆる地震空白域 となっている。理科年表によると，この 地域でM 7 を越える地震は1930年の北伊 豆地震（M7.0）だけである。一方フォ ッサマグナは現在も活動している筈であ り，もしそらなら糸魚川一静岡線の断層 も活動しているのではないかと考えられ る。この変位量を仮に約 $100 \mathrm{~km}$ とし，

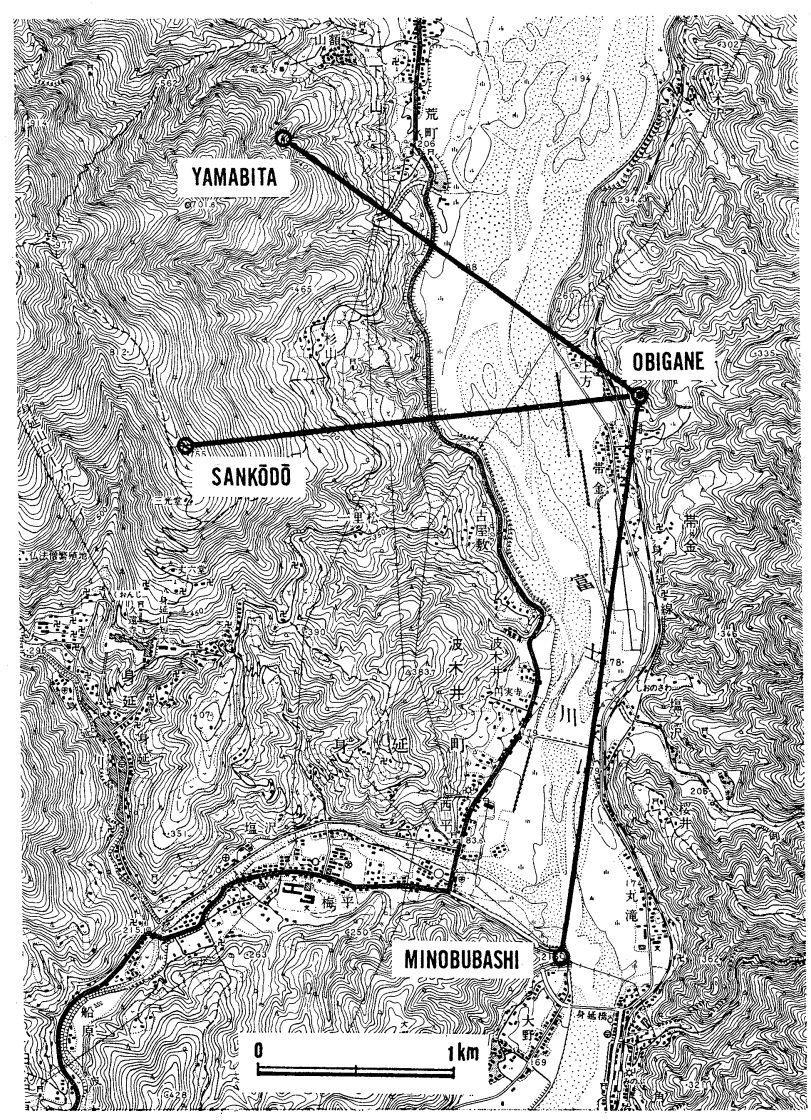

図 4 身延基線網（東大地震研）

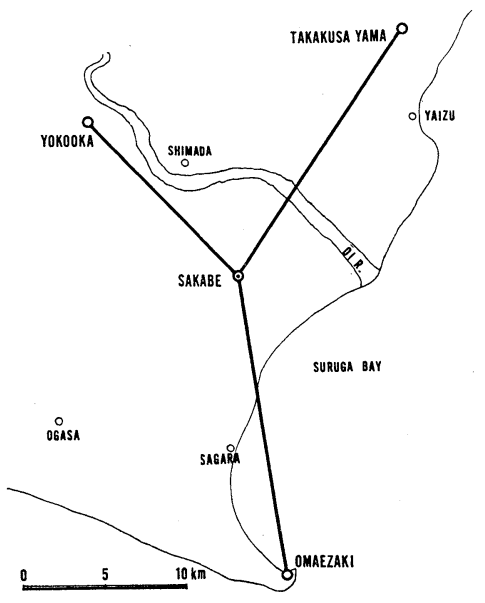

図 $5 \mathrm{~A}$ 坂部基線網（国土地理院）

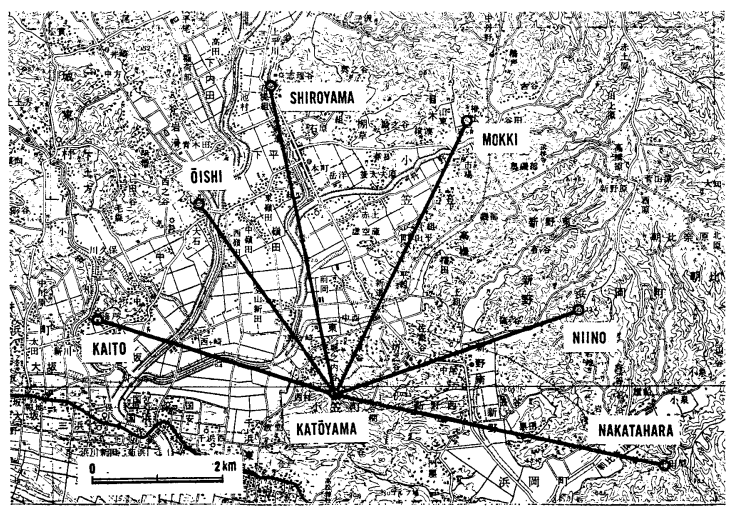

図 $5 \mathrm{~B}$ 小笠放射基線（東大地震研）

4）国土地理院藤井陽一郎氏の好意により転载する。 
断層が丹沢褶曲後の約1000万年前頃から動き始めたとすれば平均して $1 \mathrm{~cm} /$ 年の移動速度をもつことにな る。身延山の久遠寺は日蓮上人の建立といわれ，大変古い寺院であるが，特に総門は日蓮上人在世中に寄 進されたと云うから700年以上たっている事になる。身延山史（久遠寺，1973）によると，地震による建 物の大きな被害の記録は1854年の安政地震の時のみで，この他には記録はない。この断層が $1 \mathrm{~cm} /$ 年で動 いたとすればこの間に約 $7 \mathrm{~m}$ の変位があった事になり，この間に建物に大きな被害があったような地震の 記録が 1 度しかない事は大変興味深い。

このように大きな地震が起きていないのはこの地域の基盤岩の引き摺り構造に関倸があると解釈でき る。この引き摺り帯はIV節で述べたように細かい割れ目に沿った摺れの集積であるとすれば，この地域の 基盤は，小さく破砕されている為に大きな地震を起こす程大きな歪エネルギーを蓄積し得ないのではない かと考えてよい。伊豆半島沖地震 (M6.7) の時の変形範囲が $10 \mathrm{~km}$ 四方に限定されている事を考えると, フォッサマグナの地域は基盤岩がこの程度のブロックに分かれて居り, 北伊豆地震級のせいぜい $\mathrm{M} 7$ 程度 の地震しか起きないのではなかららか。

サンアンドレアス断層や根尾谷断層のように大きな断層に沿って反復して地震が起きる場合には弾性反 発的地款運動があると考えられるが，フォッサマグナでは大きな彎曲を伴う引き摺り帯があるから，もし 弾性反発的に考えるなら，この彎曲部の $30 \sim 40 \mathrm{~km}$ が一度に摺れなければならないが，この彎曲部は細か い割れ目に沿って摺れているから反発する事はなく，いわば塑性的な変形である。赤石山地や身延など断 層沿いに大きな断層がないのは，このような小さな割れ目によって歪エネルギーが解消された結果と思わ れ，もしそうであるとすればこの引き摺り帯の変形は長時間にわたり少しずつ動いたクリープに近い変形 運動なのではないかと解釈される。伊豆半島沖地震後の余効変形が長期にわたりかつかなり規模が大きい 事もこの基盤構造と関連しているように思われる。

このように考えると， 赤石山地を中心とする大地震 “空白域” は大地震の起きない機構を蔵している事 になる。地震を起こす歪エネルギーが溜るかどうかは地殼といら容器の容量にかかわって居り，100年と か120年とかの地震空白期間の長さに関わる事ではない。現在問題となっている「駿河湾」及至「東海沖」 地震の考え方にはこの点の考慮が欠けていると思われる。ましてや「駿河湾トラフへのマントルのもぐり 込み」と云う単なる仮説が即地震予知に関係しているわけではない。もしこの仮説の上に地震説が成り立 つと考えるならまずそのトラフを地殼やマントルの構造の上で証明する必要がある。災害科学は直接人の 生活に影響を及ぼす学問であるし, 特に地震予知のように大きな社会的不安に結びっく発言に当っては充 分な実証的証拠の吟味に立って行わなければならない。

フォッサマグナはナウマンの発見以来100年を経てようやく周辺地域の地質構造が明らかとなったが, 実 際の地凯運動の様子はわかっていないし，引き摺り帯の形成運動の問題も未解決である。又大きくいえば フィリピン断層やキナバル断層等北西太平洋の大断層との関連, 日本列島の彎曲の問題等, フォッサマグ ナに関連して未解決の大問題は数多く残されて居り，事の本質はまだまだ明らかにされていない。「幾多 の学説が現れては消え, 立っては倒れている間に, 吾人の知識は少しずつ歩を進めて行く事は疑いない。 雑多の学説は此意味に於いては唯事実の大建築を造り上げる為の足場に過ぎないのである」と云う寺田寅 彦の言葉はフォッサマグナ100年の研究史にそのまま当てはまるように思われる。今我々にとって必要な のは仮説ではなく，1歩ずっでも確実に歩を進める実証的なデータである。「地殼物理」と云う新しい視点 に立ってフォッサマグナの地質を瞥見し擱筆する。

\section{引用文献}

半田孝司 (1976) : 光波測量の精度についてージオジメーター700型の特性. 静大地球科学研報, 2, 1934.

石川慶司 (1972)：山梨県巨摩郡下部町付近の地質．静岡地学, 23, 35-39.

笠原慶一, 岡田 惊, 柴野睦郎, 佐々木幸一, 松本滋夫, 平井正代(1968)：光波測量による地殼変動 
の観測, 第 2 報, 関東 - 中部地方に掞ける基線網の増設と観測結果 (昭和 $41 \cdot 42$ 年度). 東大震研彙 報，46，741-758.

木村敏雄 (1959) : A sharp bent of the Median tectonic line and its relation to the Akaishi tectonic line...Tectonic significances yielded by lateral faults. Japan. J. Geol. Geogr. 30, 215-232.

, 徳山 明, B. A. Gonzales \& D. R. ANDAL (1968): Geologic structures in the Tayabas Isthmus District, Philippines. Contributions to the Geology \& Palaeontology of Southeast Asia, 49. Geol. Palaeont. Southeast Asia 4, 156-178.

小林貞一(1941) : The Sakawa Orogenic Cycle and its Bearing on the Origin of the Japanese Islands. J. Fac. Sc., Univ. Tokyo, Sec. 2, 5-7, 1-578.

-，大塚彌之助 (1938)：西南日本地体構造と中生代古地理に関する一考証(其 7 ), 地質雑，45。 松田時彦(1958)：富士川地域北部新第三系の褶曲形成史. 地質雑, 64，325-345.

宮沢芳紀，衣笠善博(1977)：石廊崎断層の余効的運動. 地調特別報告，6，105-120.

身延山久遠寺 (1968)：身延山史.

NAUman, Edmund (1893) : Neuere Beiträge zur Geologie und Geographie Japans. Petermanns

Mitt. No. 108, 45S.

大塚爾之助 $(1948)$ : 温故知新. 日本叢書, 84, 31p.

(1952)：地質構造とその研究，朋文堂, $275 \mathrm{p}$.

小川环治 (1907)：西南日本地質構造論, 地学雑, 19.

SuEss, Ed. (1888) : Antlitz der Erde 2, S. 225.

徳山 明 (1972a)：糸魚川一静岡線沿いの竜爪帯と大崩海岸の地質概説. 静大地学研報，3，7-11.

$-(1972 b)$ : 静岡地域の基盤構造の問題点. 静大教育研報 (自然科学), 23, 67-86.

-(1975a) : フォツサマグナ地域の地款運動と基盤岩の崩壊. 自然災害シンポ論文集，12，133-

134.

- (1975b) : 環太平洋造山帯の特徵, 海洋科学, 10, 44-48.

-(1975c)：1974年伊豆半島沖地震に伴う地殻運動，静大地球科学研報， 1 .

-(1977）：赤石山地の山地災害と基盤地質. 自然災害シンポ論集，14，285-286.

, 吉田鎮男 (1974) : Kinabalu Fault, a Large Strike-Slip Fault in Sabah, East Malaysia, Geol. Palaeont. Southeast Asia, 14, 171-188.

矢部長克 (1919): Problems concerning the geotectonics of the Japanese Islands: Critucak reviews of various opinions expressed by previous authours on the geotectonics. Sc. Rept., Tohoku Imp. Univ. (Geol.), 4, 75-104.

(1978年 1 月11日受理) 